УДК 37.013.42:316.624-053.6

DOI:

Орест Гук, кандидат педагогічних наук, доцент кафедри сочіальної педагогіки та корекційної освіти, Дрогобииького державного педагогічного університету імені Івана Франка

Ігор Гриник, кандидат педагогічних наук, доиент кафедри сочіальної педагогіки та корекційної освіти,

Дрогобииького державного педагогічного університету імені Івана Франка

\title{
ПРОФІЛАКТИКА СУЇЦИДАЛЬНОЇ ПОВЕДІНКИ ПІДЛІТКІВ ЯК АКТУАЛЬНА СОЦАЛЬНО-ПЕДАГОГІЧНА ПРОБЛЕМА
}

У статті розкрито загальні положення проблеми суїидальної поведінки, виявлено основні причини виникнення та чинники перебігу суйцидальної поведінки підітків, а також основні ознаки суӥцидальних тенденцій неповнолітніх. На сьогоднішній день недостатньо визначеним є питання про те, зусиллями яких фахівиів - педагогів, лікарів, психологів, соціальних педагогів, повинна проводитися робота з підлітками $з$ профілактики та корекиї суӥцидальної поведінки, адже зусилля педагогів недостатні через їх низьку обізнаність у питаннях суїииду, а можливості медиків обмежені недостатністю навиків роботи з цією категорією дітей. Охарактеризовано особливості соиіально-педагогічної профілактики означеного негативного явища, в тому числі і суїиидальної поведінки в учнівському середовищі. Визначено основні компоненти сочіально-педагогічної профілактики, проаналізовано основні методи, форми, напрями соціальнопедагогічної профілактики та корекиії у діяльності соиіального педагога та практичного психолога щчодо запобігання проблеми самогубства у підлітковому віці.

Ключові слова: суїиидальна поведінка; підліток; профілактика; соціальний педагог.

Jim. 7.

Orest Huk, Ph.D.(Pedagogy), Associate Professor of the Social Pedagogy and Correctional Education Department, Drohobych Ivan Franko State Pedagogical University

Ihor Hrynyk, Ph.D.(Pedagogy), Associate Professor of the Social Pedagogy and Correctional Education Department, Drohobych Ivan Franko State Pedagogical University

\section{PREVENTION OF SUICIDAL BEHAVIOR OF ADOLESCENTS AS A CURRENT SOCIO-PEDAGOGICAL PROBLEM}

Today, our country suffers from serious problems that are directly related to the development of negative behavior almost in all segments of the population. But the most vulnerable to various deviations, of course, are secondary school students. All this is caused by the peculiarities of age, because teenagers belong to those who are at risk.

In the article the authors reveal the general positions of the problem of suicidal behavior, identify the main causes and factors of suicidal behavior of adolescents, as well as the main signs of suicidal tendencies of minors. Internal forms of suicidal behavior, which always precede suicide in a broad or condensed form, have become widespread in adolescence. Internal suicidal behavior includes suicidal ideas (thoughts, fantasies about committing suicide) and suicidal tendencies (intentions, plans, in which there is a component of the decision and a suicide plan).

Nowadays, it is not clear enough what specialists - teachers, doctors, psychologists, social educators, should work with adolescents on the prevention and correction of suicidal behavior, because the efforts of teachers are insufficient due to their low awareness of suicide, and the capabilities of physicians are limited by lack of skills to work with this category of children.

It is noted that important elements in the prevention and correction of suicidal behavior are: psychological education, creating a positive climate, psychological and pedagogical diagnosis of suicidal tendencies, correction of suicidal tendencies and psychological counseling, systematic control and consideration of changes in personality and school students' behavior.

Features of social and pedagogical prevention of this negative phenomenon, including suicidal behavior in the student environment are described. Basic components of social and pedagogical prevention are outlined. The main methods, forms, directions of social and pedagogical prevention and correction in the activity of a social pedagogue and a practical psychologist on the prevention of suicide in adolescence are analyzed. It is determined that the activity of a social pedagogue and especially his preventive aspect plays primary importance in solving this problem.

Keywords: suicidal behavior; adolescent; prevention; social pedagogue.

остановка проблеми. Останнім часом збільшилася кількість суїцидальних спроб у шкільному віці.
Упродовж останнього десятиліття частота суїцидів у підлітків та молоді зросла майже втричі і вони посіли друге місце за частотою серед 
причин смерті в молодому віці. Ці факти надають особливої актуальності питанням діагностики, профілактики та організації допомоги учнівській молоді. Означена проблема потребує комплексних превентивних заходів, які повинні проводитися об'єднаними зусиллями психологів, психіатрів, соціологів, соціальних працівників, педагогів, юристів та людей, що оточують людину з такою проблемою. Школам сьогодні потрібні фахівці, які б опікувалися душевним самопочуттям дітей, їхніми проблемами, захопленнями та дивацтвами. 3і свого боку, такі фахівці мають бути компетентними в цій проблемі, глибоко розуміти іiї суть, причини виникнення, шляхи профілактики суїциду.

Проте є низка чинників, що утруднюють таку роботу, зокрема, відсутність методик діагностики суїцидальних ідеацій, програм системної роботи щодо виявлення груп ризику, профілактики та корекції суїцидальної поведінки. Саме на виявлення суїцидальних настроїв, ідеацій і попередження їх переходу в більш серйозні форми суїцидальної поведінки повинні б бути спрямовані профілактичні програми.

Про те, наскільки проблема профілактики суїцидальних тенденцій та корекція суїцидальної поведінки у шкільному середовищі приваблює увагу фахівців, свідчить той факт, що кількість щорічних робіт з цієї проблеми досягає кількох тисяч. Над нею плідно працювали і продовжують працювати А. Амбрумова, В. Тихоненко, Е. Шнейдман, 3. Фрейд, Е. Дюркгейм, Т. Вашека, I.Корнієнко,В.Мушинский,В.Прийменко,В.Москалець, В. Рибалка, В. Розанов, В. Силяхина та інші.

Мета статті - окреслити особливості профілактичної роботи з попередження суїцидальної поведінки у підлітковому середовищі.

Виклад основного матеріалу дослідження 3 повним обгрунтванням отриманих наукових результатів.

Проблема суїциду існувала з прадавніх часів, але саме зараз вона стає все більш актуальною внаслідок зростаючої кількості суїцидальних випадків серед молоді. Підлітковий вік $є$ для самих дітей глобальною проблемою, з якою не кожний може справитися, і як результат - підліткам легше і простіше покінчити життя суїцидом, ніж долати проблему яким-небудь іншим способом.

Довгий час сама тема суїциду була предметом табу. Всесвітня організація охорони здоров'я (BOO3) стверджує, що “це питання занадто довго сором’язливо замовчували”. У багатьох країнах тема суїциду і досі залишається під забороною, інші ж поступово починають відкрито обговорювати проблеми суїцидальних настроїв дітей та молоді. При цьому фахівці усіх країн погоджуються, що існує проблема, яку треба розв'язувати терміново. Ця проблема “епідемія" самогубств серед підлітків.

Частота суїцидальних дій протягом останніх двох десятиліть подвоїлася і Україна, як стверджує статистика, посідає одне з провідних місць у Європі за кількістю самогубств. Статистика самогубств неповнолітніх в Україні вражає: 2019 році було зафіксовано 125 випадків, а вже за рік, у 2020 - 148 випадків, а за даними ВOO3, показник в 20 осіб вже вважається критичним. Сьогодні Україна входить до групи країн з високим рівнем суїцидальної активності (більше 20 самогубств на 100 тисяч населення). При цьому національна стратегія суїцидальної превенції в Україні відсутня [5].

У загальноосвітніх навчальних закладах педагогам, практичним психологам, соціальним педагогам необхідно проводити профілактичну роботу, спрямовану на стабілізацію провокаційних ситуацій і недопущення випадків самогубств серед учнів.

Мета такої роботи:

- створення в загальноосвітніх установах сприятливого соціально-психологічного клімату, що зміцнює психічне здоров'я учнів.

Завдання:

- зміцнення соціальної захищеності учнів;

- виявлення причин, що сприяють проявам суїцидальної поведінки;

- вдосконалення організації профілактичних заходів щодо попередження суїцидів;

- розвиток соціальної активності учнів;

- залучення учнів до соціально-корисної діяльності;

- активне залучення органів учнівського самоврядування;

- організація роботи інформаційних груп з числа учнів за принципом “рівний-рівному”;

- активне залучення учнів до участі у волонтерській діяльності [7, 29].

Основним напрямом профілактики суїцидів серед учнів є освіта педагогів та батьків, в результаті якої необхідно націлювати дорослих на уважне і чуйне ставлення до дітей і молоді, на формування активної життєвої позиції і визначення дійсних ціннісних орієнтацій в житті.

Особливу увагу практичним психологам, соціальним педагогам, педагогічним працівникам у загальноосвітніх установах необхідно звернути на суїцидальну поведінку учнів: на відповідні висловлювання, натяки, що супроводжуються якими-небудь діями, спрямованими на позбавлення себе життя. 
Суїцидальна поведінка може бути наслідком соціально-психологічної дезадаптації особи, що вчиться в конфліктному середовищі.

Комплекс профілактичних заходів щодо попередження самогубств, педагогічним працівникам доцільно будувати на дослідженні причин і особливостей суїцидальної поведінки в підлітковому та юнацькому віці [1].

Алгоритм такого дослідження виглядає так:

1. Дослідження психологічної атмосфери в сім'ї, вивчення особових справ учнів, відвідини вдома, дослідження взаємодії учня з найближчим соціальним оточенням. Особливо звернути увагу на:

- несправедливе ставлення з боку батьків;

- розлучення (або подружні зради) в сім'ї учня;

- втрату одного з членів сім’і;

- незадоволеність стосунками з батьками;

- самотність;

- недостатня увага і турбота 3 боку найближчого оточення.

2. Спостереження за станом психічного i фізичного здоров'я, вивчення особових справ і медичних карток учнів. Особливо звернути увагу на:

- реальні конфлікти і мотиви його учасників;

- патологічні спадкові причини (алкоголізм батьків, психопатія, психологічні травми, залежності);

- соматичні захворювання, емоційні переживання, залежність від комп'ютерних і азартних ігор, алкоголю, наркотичних засобів.

3. Взаємодія у соціумі, вивчення міжособистісних стосунків “учень - учень”, “учень - педагог”, виявлення референтних груп. Особливо звернути увагу на:

- знедоленість, неприйняття, приниження особової гідності тощо;

- неспроможність, невдачі в навчанні, падіння престижу в колективі однолітків;

- несправедливі вимоги до учня;

- приналежність до молодіжних асоціально налаштованих груп, деструктивних сект, або переживання через погрози розправи при припиненні стосунків з ними;

- страх іншого покарання або ганьби, самоосуд за непристойний вчинок.

4. Умови, що дезадаптують:

- зниження толерантності до емоційних навантажень;

- своєрідність особистісного розвитку, несформованість навичок спілкування;

- неадекватна самооцінка власних можливостей;

- втрата розуміння цінності життя;

- втрата коханої людини;
- занижене почуття власної гідності;

- ототожнення себе з людиною, яка вчинила самогубство (цим частково пояснюються “епідемії самогубств”);

- стан перевтоми;

- панічний страх майбутнього.

Рекомендовані форми профілактичної роботи:

- Виховна година "Пошук позитивних шляхів урегулювання конфліктних ситуацій”.

- Конкурс творів про сенс життя (наприклад, “Декілька слів про пошук сенсу в житті” або “Класики літератури про сенс життя”).

- Проблемні майстерні для педагогів, батьків, учнів: "Норми неконфліктного спілкування", “Шляхи отримання допомоги в ситуації дискомфорту або стресу” тощо.

- Тренінгові заняття для учнів.

- Круглий стіл “Я на цьому світі не один”.

- Конференція "Наше духовне багатство”.

- Виховна година "Екстремальна ситуація. Як поводитися?".

- Психолого-педагогічні групові консультації на теми “Умій володіти собою”, “Прийоми зняття психологічної напруги”.

Молодь та підлітки найбільш вразливі до соціальних негараздів у суспільстві. Сьогодні зростає кількість чинників, що схиляють учнівську молодь до самогубства. Підлітковий вік є досить складним, цікавим та специфічними періодом у житті людини. Адже у цьому віці відбувається перехід 3 дитинства до дорослого життя. Світоглядні позиції стають чіткішими та категоричнішими, система взаємовідносин 3 однолітками, педагогами та батьками - більш стабільною і зрозумілою. Проте учнівській молоді притаманні сенситивність, вразливість, егоцентричність, схильність до коливань настрою та великого спектру емоцій, імпульсивність у вчинках і словах. Саме це і може стати особистісно-психологічним підгрунтям суїцидальності в учнів [2, 25].

Для профілактики самогубств серед дітей соціальний педагог або психолог може використовувати такі форми роботи:

1. Аутогенне тренування (дозволяє переключити організм суїцидента чи напруженого емоційного стану в стан емоційного спокою).

2. Психогігієнічний комплекс та прогресивна релаксація - спрямовані на поліпшення емоційного стану дітей суїцидентів.

3. Психотерапевтичні вправи слугують розв'язаних двох завдань:

- активно сприяти реалізації індивідуальної мети дітей,

- зменшити внутрішню самоагресивність. 


\section{ПРОФІЛАКТИКА СУЇЦИДАЛЬНОӤ ПОВЕДІНКИПІЛІТКІВ}

ЯК АКТУАЛЬНА СОЦІАЛЬНО-ПЕДАГОГІЧНА ПРОБЛЕМА

4. Психофізичні вправи і фітотерапія поліпшують емоційний стан дітей-суїцидентів [6].

Використання саме таких форм профілактичної роботи, вчасне діагностування та проведення вищезгаданих профілактичних заходів і занять 3 батьками, вчителями, з усіма, хто оточує особистість, індивідуальний підхід до неї забезпечить ефективне подолання суїцидальних схильностей та проявів у неї.

Також велику роль у антисуїцидальній профілактиці відіграє розвиток духовно міцної та гармонійної особистості, з міцним протисуїцидним імунітетом. Слід формувати у підлітків вміння знаходити сенс у житті, бачення життєвої перспективи та майбутнього.

Робити наголос на нерозривності зв'язків із рідними, сім'єю, суспільством, підвищувати рівень цінностей, формувати розуміння неповторності та важливості людського життя.

Якщо ж сталося так, що у підлітка не склалися довірливі стосунки з батьками, то його оточенні має бути хоча б одна доросла людина, з якою можна було б поділитися своїми хвилюваннями, проблемами чи переживаннями.

Одним із першочергових завдань щодо попередження самогубств серед неповнолітніх $\epsilon$ виявлення дітей категорій ризику, тих, чиї особистісні характеристики створюють підвищений ризик суїциду, індивідуальна робота 3 ними, системна профілактична діяльність, просвітницька робота як з учнями, так і з їхніми батьками. Дуже важливою є робота психолога у школі, саме він повинен відстежувати схильність дітей до суїциду. Діти та підлітки, які перебувають у кризовому стані, потребують підтримки оточення, членів родини, педагогів, однодумців, психокорекційної допомоги практичного психолога $[4,42]$.

Саме тому фахівці, що надають соціальнопедагогічну та психологічну допомогу групі суїцидального ризику, друзі та їх сім'ї повинні дуже ретельно підходити до здійснення профілактичних і реабілітаційних заходів, уникаючи імпульсивних висновків. Слід усвідомлювати, що особистість очікує активного втручання і емпатійного відгуку на життєву кризу, в якій вона опинилася.

Соціально-педагогічна допомога особам 3 високим суїцидальним ризиком передбачає надання дружньої допомоги (біфрендингу) i кризової інтервенції: головне - не робити спроби змінити структуру особистості людини і не намагатися вилікувати ії нервово-психічні розлади, а просто зберегти живою. Це перша і необхідна умова, без якої всі інші зусилля психотерапії та методи надання допомоги не можуть бути дієвими [3].
Важливим компонентом профілактичної роботи є інформування та просвітництво батьків, педагогів і учнів. Вона включає в себе організацію інформаційного куточка чи стенду, де буде підібрана методична література, інформація про службу “Довіри”, телефон служби, дані про фахівців, які можуть надати кваліфіковану допомогу. Також у школах доцільно проводити круглі столи, психолого-педагогічні семінари, консиліуми, на яких будуть обговорюватися теми, зв'язані з суїцидом.

Висновки. Таким чином, психологічна профілактика серед учнів та молоді вимагає комплексного підходу та використання методів, форм і засобів, які спрямовуються на вчасне виявлення суїцидальних тенденцій молоді їх попередження. Цей комплексний підхід передбачає наявність таких , та компонентів, як просвіта батьків з означеної проблеми, педагогів та учнів, діагностику суїцидальної поведінки та проявів, корекцію суїцидальних тенденцій, профілактику булінгу в учнівському середовищі, систематичне спостереження і контроль за поведінкою учнів, надання, за потреби, психологічних консультацій.

Соціально-педагогічна та психологічна допомога і підтримка передбачає подолання нереалізованості, спустошеності, безпорадності, формування нової життєвої стратегії та рівня світосприймання, набуття навичок конструктивного подолання проблем та виходу із кризових станів. Соціально-педагогічна допомога має бути скерована на стимулювання особистісної участі у відтворенні гармонійної структури життєвого світу і на подолання проблем, пов'язаних 3 адаптацією до навколишнього середовища.

Для профілактики суїцидальної поведінки серед учнівської молоді для соціальних педагогів, психологів, педагогів, батьків важливо знати не лише мотиви але й обставини, які характеризують соціальне середовище і особистість (побутова невлаштованість, соціально-правова незахищеність, невпевненість у завтрашньому дні, зниження авторитету). Слід зазначити, що тільки глибоке розуміння причин самогубства як явища та як окремого вчинку сприятиме їх мінімізації та ефективній профілактиці. Шляхи його позитивного розв'язання повинні стати першочерговими для нашого суспільства.

\section{ЛІТЕРАТУРА}

1. Брагіна М. Суїцидальна поведінка неповнолітніх: сутність, причини, профілактика: навчально-методичний посібник. Кривий Ріг, 2014. $41 \mathrm{c}$. 
2. Будагов Р.С. Булінг та його вплив на злочинність неповнолітніх. Вплив рівня дозвілля та відпочинку молоді на зниження рівня злочинності : матеріали регіонал. наук.-практ. семінару (м. Дніпро, 31 трав. 2019 р.). Дніпро : Видавець Біла К.О., 2019. С. 24-27

3. Войтко В. Характерні особливості суїциду та суїцидальної поведінки: навчально-методичний посібник. Кропивницький: КЗ “КОІППО імені Василя Сухомлинського”, 2016. 44c.

4. Живаєва Н. Психологічна допомога молоді, яка схильна до суїциду. Психолог. 2006. №1. С.42 -44 .

5. Запобігання розвитку проблеми суїциду у шкільному середовищі. Інфопедія. URL: https:// infopedia.su/7xa1de.html

6. Корнієнко I.О. Суїцид: профілактика та психологічна допомога неповнолітнім суїцидантам: навчально-методичний посібник. Львів: ЛОГППО, 2009. 94c.

7. Рибалка В.В. Психологічна профілактика суїцидальних тенденцій проблемної особистості. Київ: Шкільний світ, 2009. 128 с.

\section{REFERENCES}

1. Brahina, M. (2014). Suitsydalna povedinka nepovnolitnikh: sutnist, prychyny, profilaktyka: navchalno-metodychnyi posibnyk [Suicidal behavior of minors: essence, causes, prevention: a textbook]. Kryvyi Rih, 41 p. [in Ukrainian].

2. Budahov, R.S. (2019). Bulinh ta yoho vplyv na zlochynnist nepovnolitnikh [Bullying and its impact on juvenile delinquency]. Vplyv rivnia dozvillia ta vidpochynku molodi na znyzhennia rivnia zlochynnosti : materialy rehional. nauk.-prakt. seminaru (m. Dnipro, 31 trav. 2019 r.). - The impact of leisure and recreation of young people on crime reduction: the materials of regional. scientificpractical seminar (Dnipro, May 31, 2019). Dnipro, pp. 24-27. [in Ukrainian].

3. Voitko, V. (2016). Kharakterni osoblyvosti suitsydu ta suitsydalnoi povedinky: navchalnometodychnyi posibnyk [Characteristic features of suicide and suicidal behavior: a textbook]. Kropyvnytskyi, 44p. [in Ukrainian].

4. Zhyvaieva, N. (2006). Psykholohichna dopomoha molodi, yaka skhylna do suitsydu [Psychological help for young people who are prone to suicide]. Psykhologist. No.1. pp.42 - 44. [in Ukrainian].

5. Zapobihannia rozvytku problemy suitsydu u shkilnomu seredovyshchi [Preventing the development of suicide in the school environment]. Available at: https://infopedia.su/7xalde.html[in Ukrainian].

6. Korniienko, I.O. (2009). Suitsyd: profilaktyka ta psykholohichna dopomoha nepovnolitnim suitsydantam: navchalno-metodychnyi posibnyk [Suicide: prevention and psychological assistance to juvenile suicides: a textbook]. Lviv, 94 p. [in Ukrainian].

7. Rybalka, V.V. (2009). Psykholohichna profilaktyka suitsydalnykh tendentsii problemnoi osobystosti [Psychological prevention of suicidal tendencies of the problem personality]. Kyiv, $128 \mathrm{p}$. [in Ukrainian].

Стаття надійшла до редакції 15.01.2021

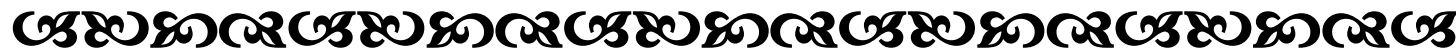

“...Виховуючи підростаюче поқоління, педагог бере найактивнішу участь у творенні майбутнъого свого народу..."

Тригорій Ващенко

украӥнський педагог

"Всі ми стоїмо на одній сщені велиқого світу, $і$ що $б$ в ньому не здійснювалося, стосується нас усіх".

Ян Амос Коменський чеський теолог, педагог

“Заглянь в середину себе: там в глибині душі є джерело добра, яқе ніколи не вичерпається, яқщо ти сам не перестанеш розқопувати його”.

МаркАврелій

римський ілператор з 161 року

\section{G580}

